\title{
Estimates of carnivore densities in a human- dominated agricultural matrix in South Africa
}

\author{
J. Philip B. Faure, Lourens H. Swanepoel, Deon Cilliers \\ JAn A. Venter and Russell A. Hill
}

\begin{abstract}
Populations of carnivore species outside protected areas may be of considerable importance for conservation, as many protected areas do not provide sufficient space for viable populations. Data on carnivore population sizes and trends are often biased towards protected areas, and few studies have examined the role of unprotected areas for carnivore conservation. We used camera-trapping data and spatial capture-recapture models to estimate population densities for four sympatric carnivores: the African leopard Panthera pardus, spotted hyaena Crocuta crocuta, brown hyaena Parahyaena brunnea and African civet Civettictis civetta in Platjan, a predominantly agricultural, mixed land-use system, South Africa. Mean densities per $100 \mathrm{~km}^{2}$ for the leopard were 2.20 (95\% CI 1.32-3.68) and 2.18 (95\% CI 1.32-3.61) for left and right flank data, respectively; spotted hyaena, 0.22 (95\% CI $0.06-0.81$ ); brown hyaena, 0.74 (95\% CI 0.30-1.88); and African civet 3.60 (95\% CI 2.34-5.57; left flanks) and 3.71 (95\% CI 2.41-5.72; right flanks). Our results indicate that although densities are lower than those reported for protected areas, humans and predators coexist in this unprotected agricultural matrix. We suggest that increased conservation effort should be focused in such areas, to mitigate human-carnivore conflicts. Our study improves the knowledge available for carnivore populations on privately owned, unprotected land, and may benefit conservation planning.
\end{abstract}

J. PHILIP B. FAURE ${ }^{*} \dagger$ (Corresponding author, (1) orcid.org/0000-0001-5183-5487) Panthera, 8 W 40th Street 18th Floor, New York, New York 10018, USA

E-mail philip.faure@yahoo.com

LOURENS H. SWANEPOEL $\$$ (망 orcid.org/0000-0002-9955-8076) African Institute for Conservation Ecology, Levubu, South Africa

Deon Cilliers (잉 orcid.org/0000-0003-1481-9693) Cheetah Outreach Trust, Somerset West, South Africa

Jan A. VenteR $\$$ (ㅇ) orcid.org/0000-0002-4548-2571) Mammal Research Institute, University of Pretoria, Pretoria, South Africa

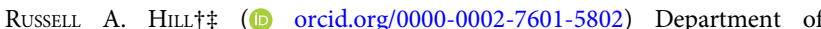
Anthropology, Durham University, Durham, UK

*Also at: School of Natural Resource Management, Nelson Mandela University, George, South Africa

$\dagger$ Also at: Primate and Predator Project, Lajuma Research Centre, Makhado, South Africa

¥Also at: Department of Zoology, University of Venda, Thohoyandou, South Africa

$\S$ Also at: REHABS International Research Laboratory-CNRS, Paris, France; Université Claude-Bernard Lyon 1, Lyon, France; Nelson Mandela University, George, South Africa

Received 10 June 2020. Revision requested 21 January 2021.

Accepted 12 March 2021. First published online 29 September 2021.
Keywords Agricultural area, camera trapping, civet, human-wildlife conflict, hyaena, leopard, spatial capturerecapture, South Africa

Supplementary material for this article is available at doi.org/10.1017/So03060532100034X

\section{Introduction}

Carnivore populations are undergoing range contractions globally (Wolf \& Ripple, 2017), with declines largely a result of anthropogenic threats, including persecution, hunting, poaching, habitat loss and insufficient prey (Wolf \& Ripple, 2016). As such, protected areas are considered essential for effective species conservation (Le Saout et al., 2013). However, there is evidence of cross-boundary impacts of human activities on protected areas, ranging from edge effects on specific species (Balme et al., 2010) to system-wide changes in ecosystem processes (Veldhuis et al., 2019). Unprotected areas may provide favourable habitat and connectivity for various species (Kent \& Hill, 2013; Swanepoel et al., 2013; Pitman et al., 2017a). Consequently, there is increasing interest in conservation and mitigation actions in buffer areas around protected areas and in the broader agricultural matrix (Woodroffe \& Ginsberg, 1998; van der Meer et al., 2014).

There is growing evidence of the importance of the agricultural matrix to wildlife and landscape conservation. For example, small carnivores persist in rural smallholder agroecosystems (Nogeire et al., 2013; Williams et al., 2018a) where they provide important ecosystem services (Ćirović et al., 2016; Williams et al., 2018a). Similarly, the agricultural matrix can provide stepping stones in species migration or dispersal (Davies-Mostert et al., 2012; Fattebert et al., 2013) or form corridors to connect protected areas (Pitman et al., 2017a). Although protected areas cover c. $15 \%$ of the terrestrial surface (Geldmann et al., 2019), pressures from human activities (especially land conversion for agriculture) inside protected areas may often be significantly higher than outside these areas in South America, South-east Asia and sub-Saharan Africa (Geldmann et al., 2019). In South Africa, c. $9.2 \%$ of land is protected formally, with $25.6 \%$ of this area comprising privately owned protected areas (De Vos \& Cumming, 2019). However, protected areas are not impervious to the landscapes within which they exist, or to changes in and demands from society (De Vos et al., 
2019), in some cases even resulting in protected area downgrading, downsizing and degazettement (Mascia \& Pailler, 2011).

Carnivores are vulnerable to anthropogenic landscape alterations such as land conversion for agriculture. Agricultural intensification leads to habitat loss and fragmentation, one of the most serious threats to biodiversity (Šálek et al., 2014). Globally, the growth of human populations and per capita consumption generates increasing agricultural pressure on natural resources (Dobrovolski et al., 2011). Understanding how biodiversity is affected by agricultural landscapes is therefore of particular importance to species conservation (Shamoon et al., 2017). Nonetheless, these landscapes may be of considerable value for carnivore species (Kent \& Hill, 2013). In South Africa, carnivores in agricultural landscapes face threats in addition to habitat fragmentation. For example, in some areas the natural prey base has been depleted by bushmeat poaching or unsustainable hunting (Wolf \& Ripple, 2016; Rogan et al., 2017), or replaced with livestock or game farming (Grossmann et al., 1999). Legal and illegal persecution where carnivores compete for food with people can often result in trapping, poisoning or shooting to mitigate conflict (Nattrass \& Conradie, 2018). Consequently, habitats shared between people and carnivores can function as a population sink, in which persistence is compromised by unsustainable offtake (Abade et al., 2018). However, crop farming areas may offer certain carnivore species alternative food sources. For example, small- to medium-sized carnivores may benefit from rodent populations in agricultural cropping areas (Williams et al., 2018a), whereas in livestock farming areas some scavenging species may take advantage of livestock mortalities and so provide organic waste disposal services (O'Bryan et al., 2018). Kent \& Hill (2013) suggest that a significant proportion of the global brown hyaena population lives in unprotected areas such as livestock farms. Protected areas are not always large enough to conserve viable populations of animals, especially for wide-ranging species such as the leopard Panthera pardus, hyaena Crocuta crocuta and Parahyaena brunnea and African wild dog Lycaon pictus (Swanepoel et al., 2013). Furthermore, c. 68\% of the habitat most suitable for leopards in South Africa lies outside protected areas (Swanepoel et al., 2013).

Although unprotected areas and the agricultural matrix can play an important role in carnivore conservation, little research has focused on this (Shamoon et al., 2017). Here we use an intensively utilized agricultural landscape as a model to estimate the density of four sympatric carnivore species: the African leopard, spotted and brown hyaenas, and African civet Civettictis civetta. We focus on these species because they have unique coat patterns that facilitate individual recognition and robust density estimates, and they are exposed to varying levels of human-carnivore conflict. African leopards and spotted hyaenas are frequently subjected to persecution (Gusset et al., 2009; Thorn et al.,
2012; Constant et al., 2015), and we expect their densities to be low in comparison to similar habitats in protected areas. Brown hyaenas may experience less conflict than leopards (Constant et al., 2015), but we still expect their densities to be low as they are persecuted using the same non-selective trapping techniques, and may rely on leopard kills for scavenging opportunities (Williams et al., 2018b). The African civet is the least conflict-prone species, although occasionally subjected to conflict where poultry farming occurs (Croes et al., 2008), and we expect its density to be similar to that in protected areas. Locating our study in a livestock, game and crop farming area enables us to investigate carnivore densities in a human-dominated landscape where there is conflict with carnivores. We compare our density estimates for the four species to density estimates in both protected and unprotected areas elsewhere in southern Africa, to gauge the conservation value of the agricultural matrix.

\section{Study area}

The study area is in Platjan, in northern Limpopo Province, South Africa, where it borders Botswana (Fig. 1), within the Blouberg (Ward 20) Municipal Area, which has an estimated human population of 9,154 (240 people per 100 $\mathrm{km}^{2}$; Statistics South Africa, 2011). Forty-eight per cent of the population is unemployed and only $15.9 \%$ have completed high school (Statistics South Africa, 2011). Fortythree per cent of this region's population is aged o-19 years, $33 \%$ 20-39, and $24 \%>40$ years (Statistics South Africa, 2011).

The vegetation is classified as Limpopo Sweet Bushveld (Mucina \& Rutherford, 2006), and altitude is $600-1,000 \mathrm{~m}$. It is a summer (December-February) rainfall region with dry winters (June-August) and a mean annual rainfall of 300-400 mm (Mucina \& Rutherford, 2006).

The area comprises a mixed land-use system, predominantly commercial crop farming (dominated by butternut squash, onion, potato and corn), livestock farming (mostly cattle and goats), game farming for hunting, and one ecotourism reserve. The camera-trapping grid lies within 29 privately owned farms, owned by 18 landowners; $41.4 \%$ of the properties were utilized for hunting and game farming, $34.5 \%$ for mixed agricultural farming practices (crop and livestock), $10.3 \%$ for livestock farming and hunting, $7 \%$ for mixed land uses (crop, livestock and hunting), 3.4\% for crop farming, and $3.4 \%$ for ecotourism. All of the properties are surrounded by fencing, with the majority being electrified and c. $1.8 \mathrm{~m}$ high to keep game species in. Nonetheless, most of the fences have multiple holes, often created by warthogs Phacochoerus africanus, providing some connectivity between properties.

Wildlife and habitat within the area are exposed to various anthropogenic threats and disturbances such as legal and illegal, selective and non-selective predator control 


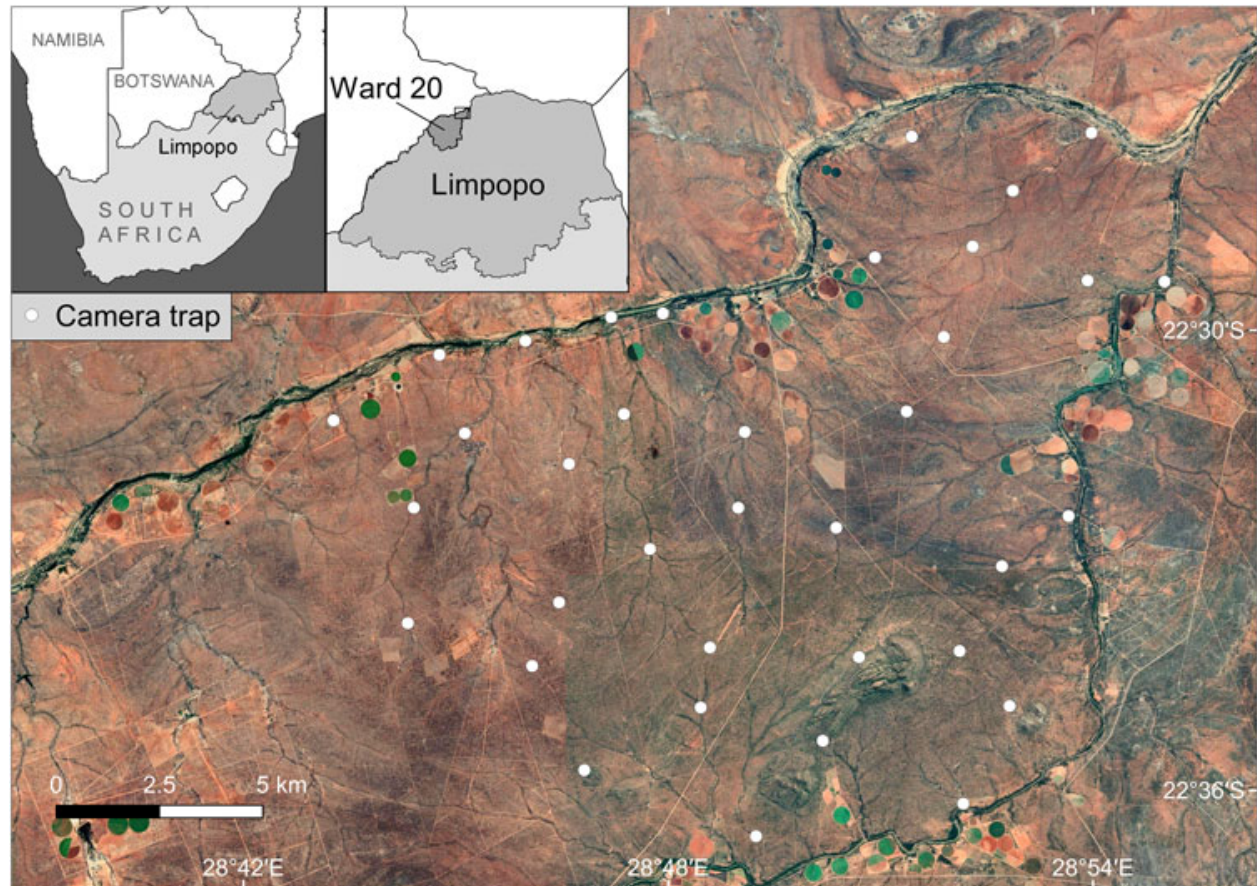

FIG. 1 Study area, with camera-trap locations in the Platjan area, Limpopo Province, South Africa (background map (C) 2021 Google, Maxar Technologies, CNES/Airbus). (such as trapping, poisoning, shooting and snaring), and the transformation of habitat for agricultural practices. This reflects the situation in the province more broadly (Thorn et al., 2012; Pitman et al., 2015).

\section{Methods}

We surveyed carnivores using camera traps during 1 August-29 October 2017, deploying 72 camera traps at 36 stations on average $2.04 \mathrm{~km}$ apart, with a maximum spacing of $2.86 \mathrm{~km}$ (Fig. 1). This spacing minimized chances of gaps between camera traps being large enough to encompass the entire home range of an individual of one of our study species, so that all individuals had a probability of capture $>0$. Roads and trails were actively searched for carnivore scats and tracks, to guide selection of sites for camera traps, thereby maximizing the probability of detecting the four carnivore species. Camera traps were set at $\mathrm{c}$. $40 \mathrm{~cm}$ above the ground, in pairs, perpendicular to the trail and level with the ground, to maximize chances of detection. No bait or lures were used. Trigger time between consecutive photographic captures was set to the minimum possible time for each camera, to maximize the possibility of obtaining suitable images of both flanks for individual identification from pelage patterns. The most suitable area for individual identification of leopards, spotted hyaenas and African civets is their flanks, whereas brown hyaenas can be identified by the stripe patterns on their legs. We used a Reconyx (either a $\mathrm{HC}_{500}$ or HC600 model; Reconyx, Holmen, USA) camera at each station, paired with either another Reconyx or a Bushnell Trophy Camera (Bushnell, Overland Park, USA), Browning Recon Force (Browning
Trail Cameras, St. Louis, USA), or Cuddeback Long Range C2 camera (Cuddeback, Green Bay, USA). The total area covered by the camera-trapping grid was $195 \mathrm{~km}^{2}$. We considered this an adequate size for spatial capture-recapture analyses as it is large enough to cover estimates of mean home range for our study species from similar environments (Supplementary Table 1). We visited the camera traps at least once per month to change batteries and memory cards, clear vegetation in front of the camera's field of view, and to ensure proper functioning. The survey period was limited to 90 days so as not to violate the capture-recapture closure assumption (Kery \& Royle, 2016).

Individuals of the focal species were identified based on their unique coat patterns, using the open-source pattern recognition software Hotspotter (Crall et al., 2013), and then verified manually. We selected our sampling occasions to stretch across midnight (from 12.00 to 11.59 the following day) as all our study species are predominantly nocturnal, with sampling occasions set to 1-day periods. We constructed spatial capture histories for all the identified individuals for the 90 sampling occasions. As we did not obtain images of both flanks of all individuals, we estimated density first by excluding individuals for which we only had leftflank images, and then by excluding those for which we only had right-flank images, and compared the results.

We used a maximum likelihood modelling approach to fit spatial capture-recapture models to estimate population densities of the four species. Models were implemented using the package secr 4.2.0 in $R$ 3.6.2 (R Development Core Team, 2016). Density was estimated within the state space, which consists of an explicit spatial region within which sampling occurs. This area includes the trapping 
TABLE 1 Total number of captures, number of captured individuals, number of individuals recaptured o- 8 times, and the mean \pm SE of the mean maximum distance moved (MMDM) for four carnivore species in Platjan, South Africa (Fig. 1). Left and right flank data are denoted by $\mathrm{L}$ and $\mathrm{R}$, respectively.

\begin{tabular}{|c|c|c|c|c|c|c|c|c|c|c|c|c|}
\hline \multirow[b]{2}{*}{ Species } & \multirow[b]{2}{*}{ Captures } & \multirow[b]{2}{*}{ Individuals } & \multicolumn{9}{|c|}{ Number of recaptures } & \multirow{2}{*}{$\begin{array}{l}\text { MMDM }(\mathrm{m}) \\
\text { Mean } \pm \text { SE }\end{array}$} \\
\hline & & & 0 & 1 & 2 & 3 & 4 & 5 & 6 & 7 & 8 & \\
\hline Leopard Panthera pardus (L) & 109 & 21 & 10 & 3 & 2 & 1 & 2 & 1 & 1 & 1 & 0 & $9,856 \pm 1,722$ \\
\hline Leopard (R) & 111 & 19 & 8 & 4 & 3 & 0 & 2 & 1 & 0 & 1 & 0 & $7,965 \pm 1,660$ \\
\hline Spotted hyaena Crocuta crocuta & 69 & 9 & 1 & 2 & 1 & 0 & 3 & 1 & 0 & 0 & 1 & $10,832 \pm 2,174$ \\
\hline Brown hyaena Parahyaena brunnea & 85 & 14 & 4 & 2 & 2 & 2 & 1 & 1 & 2 & 0 & 0 & $10,418 \pm 1,773$ \\
\hline African civet Civettictis civetta (L) & 180 & 43 & 21 & 13 & 7 & 1 & 0 & 1 & 0 & 0 & 0 & $7,069 \pm 1,037$ \\
\hline African civet (R) & 172 & 44 & 25 & 11 & 6 & 1 & 0 & 1 & 0 & 0 & 0 & $6,919 \pm 1,119$ \\
\hline
\end{tabular}

grid and a buffer zone, to ensure that the activity centres of all individuals potentially exposed to sampling would be included in the buffer area (Kery \& Royle, 2016). We used the number of days a camera station was active (i.e. trap-nights) as a variable in the detection process. We examined the effect of varying the buffer size $(5-45 \mathrm{~km}$, with $2.5 \mathrm{~km}$ increments; Supplementary Fig. 1) to test its influence on predicted density estimates, using buffer sizes that were sufficiently large to include all activity centres of individuals exposed to trapping. We assumed buffers were large enough if the density estimates began to plateau with increasing buffer size and if the model's buffer was at least 3 times the size of $\sigma$ (the spatial scale parameter). We used a buffer of $25 \mathrm{~km}$ for the civet and leopard, $30 \mathrm{~km}$ for the brown hyaena and 40 $\mathrm{km}$ for the spotted hyaena. The state space was described by 14,500 (civet and leopard), 19,119 (brown hyaena), and 30,219 (spotted hyaena) equally spaced points in a regular grid with a mesh size of $0.25 \mathrm{~km}^{2}$. We assumed carnivores could utilize anthropogenically modified areas (e.g. agricultural fields) in the study area, and consequently all possible home range centres in the state space were marked as suitable habitat in the input files.

\section{Results}

The 90-day camera-trap survey period comprised 2,988 trap-nights, with each individual camera-trap station active for a mean of 88 days (range: 49-90 days). We captured leopards at 28 camera-trap stations ( $78 \%$ of the total) and obtained on average $3.03 \pm$ SE 0.84 and $3.08 \pm$ SE 0.85 independent captures for left and right flank data at each station, respectively (Table 1 ). For the spotted and brown hyaenas there were no identification discrepancies between the left and right flank data. Spotted hyaenas were captured at 17 camera-trap stations (47\%) and we obtained on average $1.89 \pm$ SE 0.64 independent captures. Brown hyaenas were captured at 23 camera-trap stations (64\%) and we obtained on average $2.36 \pm$ SE 0.51 independent captures. African civets were captured at 32 camera-trap stations (89\%) and we obtained on average 5.00 \pm SE 0.95 left flank and $4.78 \pm$ SE 0.94 right flank independent captures. We identified 21 and 19 individual adult leopards (left and right flank data, respectively), nine spotted hyaenas, 14 brown hyaenas, and 43 and 44 civets (left and right flank data, respectively). We identified one subadult leopard and one subadult spotted hyaena but no juveniles. For leopards, we recorded nine adult males, eight adult females, and five individuals of unknown sex. We could not reliably sex spotted hyaenas, brown hyaenas or African civets. Leopards had the highest baseline detection rate (i.e. the probability of detecting an individual at its activity centre), go, and the two hyaena species had the largest estimated spatial scale parameter (i.e. the rate of decrease in encounter probability as a function of distance to the camera trap), $\sigma$. Density estimates ranged from 0.22 spotted hyaenas per $100 \mathrm{~km}^{2}$ to 3.71 African civets per $100 \mathrm{~km}^{2}$ (Table 2).

\section{Discussion}

Our results indicate that carnivores can co-occur with humans in agricultural areas and thus illustrates the potential importance of such areas for the conservation of freeranging carnivore species. Although our estimates of density fall within the range of densities reported for the leopard, brown hyaena and African civet in both protected and unprotected areas, these estimates were lower in comparison to similar environments elsewhere, and closer to estimates reported for more arid regions.

The estimate of 2.2 leopards per $100 \mathrm{~km}^{2}$ is at the lower end of the range reported from 21 camera-trapping surveys in seven protected areas in Limpopo Province, South Africa (0.87-6.55 per $100 \mathrm{~km}^{2}$; Rogan et al., 2019). Although some of the highest recorded densities of southern African leopards came from unprotected land (Chase Grey et al., 2013, but see Williams et al., 2017) our density estimates are similar to those for other farming areas and slightly below those in protected areas (Fig. 2).

The estimate of 0.219 spotted hyaenas per $100 \mathrm{~km}^{2}$ was much lower than previous studies in similar environments such as the Ngamiland District (Rich et al., 2019) and central Tuli, Botswana (Vissia et al., 2021), but similar to estimates from farmlands in the Tsauchab River Valley, Namibia 
TABLE 2 The buffer width, and estimated mean parameter values \pm SE and range from spatial capture-recapture models for four carnivore species in Platjan: estimated density, detection rate $(g o)$, and spatial scale parameter $(\sigma)$. Left and right flank data are denoted by L and R, respectively.

\begin{tabular}{llllr}
\hline Species & Buffer $(\mathrm{km})$ & Density \pm SE (range), per $100 \mathrm{~km}^{2}$ & $g 0 \pm$ SE (range) & $\sigma \pm$ SE (range), km \\
\hline Leopard (L) & 25 & $2.201 \pm 0.586(1.318-3.675)$ & $0.012 \pm 0.002(0.009-0.016)$ & $4.716 \pm 0.539(3.773-5.895)$ \\
Leopard (R) & 25 & $2.180 \pm 0.570(1.316-3.609)$ & $0.013 \pm 0.002(0.010-0.018)$ & $4.291 \pm 0.416(3.549-5.186)$ \\
Spotted hyaena & 40 & $0.219 \pm 0.165(0.059-0.812)$ & $0.018 \pm 0.012(0.005-0.061)$ & $11.159 \pm 3.180(6.454-19.295)$ \\
Brown hyaena & 30 & $0.744 \pm 0.372(0.295-1.876)$ & $0.007 \pm 0.002(0.004-0.012)$ & $8.090 \pm 1.811(5.245-12.479)$ \\
African civet (L) & 25 & $3.605 \pm 0.809(2.335-5.566)$ & $0.008 \pm 0.001(0.006-0.010)$ & $5.945 \pm 0.626(4.839-7.304)$ \\
African civet (R) & 25 & $3.711 \pm 0.829(2.407-5.719)$ & $0.008 \pm 0.001(0.006-0.010)$ & $5.959 \pm 0.632(4.843-7.332)$ \\
\hline
\end{tabular}
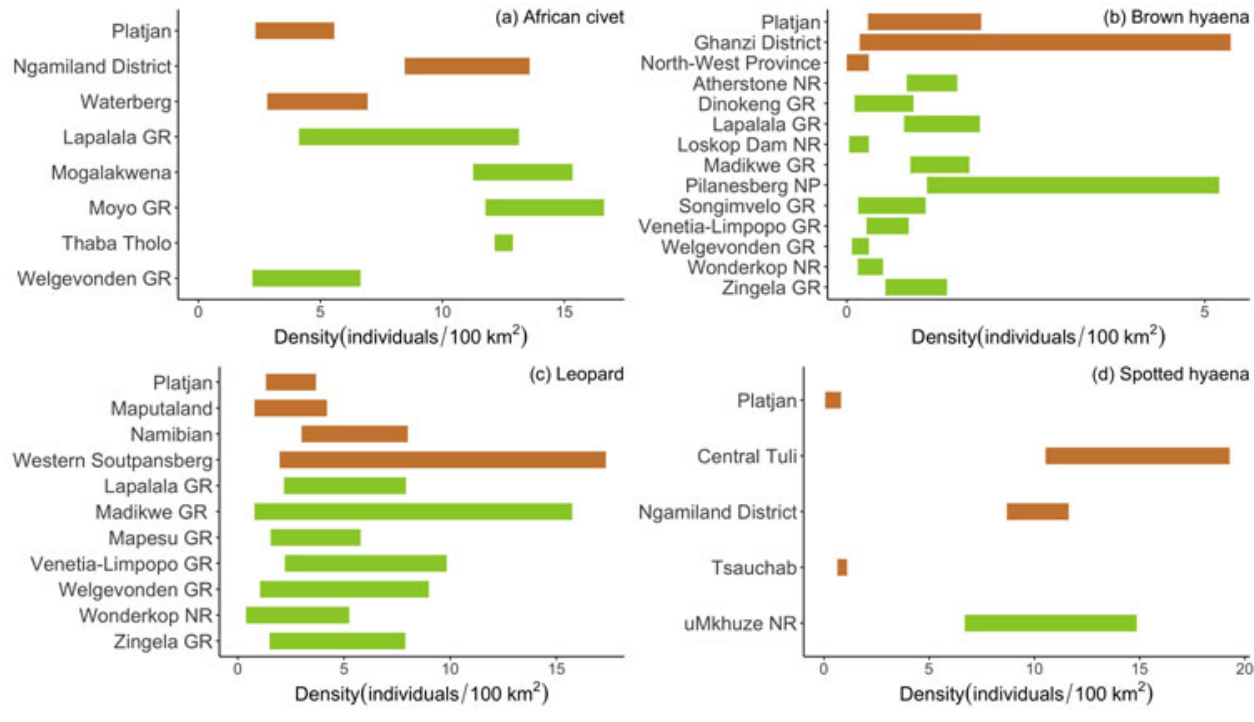

Farmlands
FIG. 2 Estimates of density ranges (individuals $/ 100 \mathrm{~km}^{2}$ ) from spatial capture-recapture studies of (a) the African civet Civettictis civetta, (b) brown hyaena Parahyaena brunnea, (c) spotted hyaena Crocuta crocuta and (d) leopard Panthera pardus in protected and unprotected areas across southern Africa, including this study (top bar in each case). See Supplementary Table 2 for details of sources. GR, Game Reserve; NR, Nature Reserve.
(Fouché et al., 2020; Fig. 2). Call-up surveys in different vegetation types in Kruger National Park, South Africa recorded densities of 2.6-21.1 individuals per $100 \mathrm{~km}^{2}$ (Mills et al., 2001), and clans of up to 133 individuals per $100 \mathrm{~km}^{2}$ have been estimated in Ngorongoro, Tanzania (Höner et al., 2005). Although density estimates from callup studies and spatial capture-recapture cannot be compared directly, the results nevertheless suggest substantial differences between areas, suggesting significant anthropogenic influence on the Platjan population.

The estimate of 0.74 brown hyaenas per $100 \mathrm{~km}^{2}$ was similar to numbers extrapolated from occupancy estimates in the North-West Province, South Africa (Thorn et al., 2011), but lower than in similar environments such as the Ghanzi District, Botswana (although within the 95\% confidence intervals; Kent \& Hill, 2013), Pilanesberg National Park, South Africa (Thorn et al., 2009), and Central Kalahari Game Reserve, Botswana (Winterbach et al., 2017; Fig. 2). The highest recorded densities are from reserves in Namibia (Okonjima Nature Reserve; Edwards et al., 2019), South Africa (Kwandwe Nature Reserve; Welch \& Parker, 2016), and the central Tuli block, Botswana (Vissia et al., 2021). These far exceed our density estimate (Supplementary Table 2), although assumptions about fence permeability may account for some of these differences (Williams et al., 2021). Although there are challenges in comparing density estimates given some of the methods used (occupancy models and track counts; Balme et al., 2009; Rich et al., 2014; Rogan et al., 2019), our densities are similar to brown hyaena densities in similar habitats where spatial capture-recapture methods have been used (Williams et al., 2021; Fig. 2, Supplementary Table 2).

Contrary to our expectations, the density of 3.6-3.7 civets per $100 \mathrm{~km}^{2}$ is lower than other recorded densities (Fig. 2), although within the range of densities from three sites in the Waterberg Biosphere Reserve (Isaacs et al., in press). Higher densities recorded in South Africa (Amiard, 2014) and Botswana (Rich et al., 2019) suggest that civets may be subject to significant anthropogenic pressure in our study area.

Several factors may be driving carnivore population densities. Unlike previous studies that were predominantly in protected areas, the Blouberg Ward 20 region within which our study was conducted had a human population of 240 people per $100 \mathrm{~km}^{2}$ (Statistics South Africa, 2011), and there was frequent traffic such as crop and livestock transportation, and movement of agricultural vehicles. Roads 
may have negative impacts on wildlife habitat use and cause habitat loss, fragmentation and degradation (van der Ree et al., 2011; Shannon et al., 2014). The high human population and associated anthropogenic disturbances may be negatively affecting carnivore survival and space use in our study area, and could explain the lower than expected densities of the four study species. Moreover, carnivores are persecuted where they compete for wild prey (Pitman et al., 2017b) or livestock (Constant et al., 2015) with humans, and in areas where there is a lack of inexpensive protein substitutes for people, carnivores may be affected by bushmeat poaching activities (Lindsey et al., 2013; Rogan et al., 2017).

Fencing has been widely used in South Africa to protect livestock and game species from carnivores, creating barriers that impede movement and ranging behaviour, contributing to habitat fragmentation, and influencing long-term survival of carnivore populations (Cozzi et al., 2013). In our study area most of the properties are fenced. Although we recorded multiple recaptures of the same individuals at different camera-trap stations, demonstrating that movement between fenced properties does occur, carnivore densities may still be negatively influenced by the impediment to movement imposed by fencing.

Carnivore densities are also related to the abundance and biomass of prey (Hayward et al., 2007). Even though game farming may provide increased hunting and scavenging opportunities for carnivores it may also be detrimental for their conservation, especially where carnivore species compete with people for prey (Pitman et al., 2017b). Higher densities of brown hyaenas on cattle farms than in neighbouring protected areas (Kent \& Hill, 2013) may be a result of scavenging opportunities from larger predators in these areas or of livestock mortalities, possibly related to disease (Maude \& Mills, 2005). Three of our study species are known to scavenge (spotted hyaenas: Cooper et al., 1999; brown hyaenas: Faure et al., 2019; African civet: Daniel et al., 2008), and the leopard, although not characterized as a scavenger, may take advantage of opportunities to scavenge (Hayward et al., 2006). Thus, the agricultural matrix appears to present both opportunities and threats for carnivores.

There are several caveats to our research. We assumed that all home range centres within the state space were suitable habitat, but some areas may be more suitable than others (e.g. the small ecotourism reserve vs crop farming areas with more human activity). Spatial capture-recapture models assume there is a decline in detection probability with increasing distance between the detector and an animal's home range centre (Kery \& Royle, 2016). However, heterogeneity in an animal's use of space may be a further source of variation in detection probability, and failure to account for this may bias density estimates (Efford, 2014); our study did not account for any heterogeneity in animal space use or test for any significant influence of this. Our study area is subject to higher human activity during the day, from agricultural practices, than at night, which could affect the times when carnivores were detected (Gaynor et al., 2018). However, as the four carnivore species are nocturnal, and our sampling occasions incorporated the full duration of the night (overcoming the so-called midnight problem; Jordan et al., 2011), we assumed that human activity did not affect the detection process within a spatial capture-recapture framework, but this assumption may not hold for other systems.

Although the estimates of the density of our four study carnivore species were lower than estimates for protected areas, our research highlights the potential value of the agricultural matrix for biodiversity conservation. The majority of data available on population sizes and trends of carnivores are for protected areas (Swanepoel et al., 2015), an issue that could bias conservation strategies. Human-dominated and altered landscapes can have negative effects on some wildlife populations (Ramesh \& Downs, 2015), and there is evidence of human pressure on the carnivore populations in Platjan (D. Cilliers, unpubl. data). Nevertheless, our findings demonstrate that people and carnivores can coexist in shared landscapes, and therefore the agricultural community could potentially play an important role in carnivore conservation.

Acknowledgements We thank Earthwatch through the Neville Shulman Award, and Nelson Mandela University, for funding; Marc Engler, Annie Casey, Nadine-Josie Holmes, Jessica Jones, Chris Duff, Anasthasia Sanchez De Launay, Maya Broadbank, Sarah Marsh, Max Hargreaves, Aaron Eastwood, and Joe Jacobs for assistance with camera-trap image classification and fieldwork; Platjan landowners for permission to access their properties; Markus Jebsen, Riley De Charmoy Bouchet, Syanne Kirby, and the Limpokwena Nature Reserve for their hospitality during data collection; and a reviewer and the Editor for their constructive feedback.

Author contributions Study design, fieldwork: JPBF, RAH; data analysis: JPBF, RAH, LHS; writing: JPBF, RAH, LHS, JAV, DC.

\section{Conflicts of interest None.}

Ethical standards This research abided by the Oryx guidelines on ethical standards. Permission was obtained from all landowners to conduct camera-trap research on their respective properties, and, according to Nelson Mandela University's ethical criteria, the research design did not require approval.

\section{References}

Abade, L., Cusack, J., Moll, R.J., Strampelli, P., Dickman, A.J., Macdonald, D.W. \& Montgomery, R.A. (2018) Spatial variation in leopard (Panthera pardus) site use across a gradient of anthropogenic pressure in Tanzania's Ruaha landscape. PLOS ONE, 13, e0204370.

Amiard, P. (2014) Ecology of the African civet (Civettictis civetta) in three different vegetation types of South Africa: study of the population density, the habitat use and the diet. MSc thesis, University of Reims Champagne-Ardenne, Reims, France.

Balme, G.A., Hunter, L.T. \& Slotow, R. (2009) Evaluating methods for counting cryptic carnivores. Journal of Wildlife Management, 73, $433-441$. 
Balme, G.A., Slotow, R. \& Hunter, L.T.B. (2010) Edge effects and the impact of non-protected areas in carnivore conservation: Leopards in the Phinda-Mkhuze Complex, South Africa. Animal Conservation, 13, 315-323.

Chase Grey, J.N., Kent, V.T. \& Hill, R.A. (2013) Evidence of a high density population of harvested leopards in a montane environment. PLOS ONE, 8, e82832.

Ćirović, D., Penezić, A. \& Krofel, M. (2016) Jackals as cleaners: ecosystem services provided by a mesocarnivore in human-dominated landscapes. Biological Conservation, 199, 51-55.

Constant, N.L., Bell, S. \& Hill, R.A. (2015) The impacts, characterisation and management of human-leopard conflict in a multi-use land system in South Africa. Biodiversity and Conservation, 24, 2967-2989.

Cooper, S.M., HoleKamp, K.E. \& Smale, L. (1999) A seasonal feast: long-term analysis of feeding behaviour in the spotted hyaena (Crocuta crocuta). African Journal of Ecology, 37, 149-160.

Cozzi, G., Broekhuis, F., Mcnutt, J.W. \& Schmid, B. (2013) Comparison of the effects of artificial and natural barriers on large African carnivores: implications for interspecific relationships and connectivity. Journal of Animal Ecology, 82, 707-715.

Crall, J.P., Stewart, C.V., Berger-Wolf, T.Y., Rubenstein, D.I. \& Sundaresan, S.R. (2013) Hotspotter-patterned species instance recognition. In IEEE Workshop on Applications of Computer Vision, pp. 230-237. Institute of Electrical and Electronic Engineers, Piscataway, USA.

Croes, B., Buij, R., van Dalen, J., De Iongh, H., Croes, B.M., BAUER, H. \& DE IONGH, H.H. (2008) Livestock-carnivore conflicts: results of an inventory around Bénoué National Park, Cameroon. In Management and Conservation of Large Carnivores in West and Central Africa (eds B. Croes, R. Buij, H.H. de Iongh \& H. Bauer), pp. 29-40. Proceedings of an International Seminar, CML/CEDC, Maroua, Cameroon.

Daniel, W., Eniang, E.A., Bekelle, A., Balakrishnan, M. \& EGWALI, E.C. (2008) Food types and feeding ecology of African civets (Civettictis civetta) in Jimma, Ethiopia. Revue d'Ecologie, 63, 283-288.

Davies-Mostert, H.T., Kamler, J.F., Mills, M.G.L., Jackson, C.R. Rasmussen, G.S.A., Groom, R.J. et al. (2012) Long-distance transboundary dispersal of African wild dogs among protected areas in Southern Africa. African Journal of Ecology, 50, 500-506.

De Vos, A., Clements, H.S., Biggs, D. \& Cumming, G.S. (2019) The dynamics of proclaimed privately protected areas in South Africa over 83 years. Conservation Letters, 12, e12644.

De Vos, A. \& Cumming, G.S. (2019) The contribution of land tenure diversity to the spatial resilience of protected area networks. People and Nature, 1, 331-346.

Dobrovolski, R., Diniz-Filho, J.A., Loyola, R.D. \& De Marco, P. (2011) Agricultural expansion and the fate of global conservation priorities. Biodiversity and Conservation, 20, 2445-2459.

Edwards, S., Noack, J., Heyns, L. \& Rodenwoldt, D. (2019) Evidence of a high-density brown hyena population within an enclosed reserve: the role of fenced systems in conservation. Mammal Research, 64, 519-527.

EFFORD, M.G. (2014) Bias from heterogeneous usage of space in spatially explicit capture-recapture analyses. Methods in Ecology and Evolution, 5, 599-602.

Fattebert, J., Dickerson, T., Balme, G., Slotow, R. \& Hunter, L. (2013) Long-distance natal dispersal in leopard reveals potential for a three-country metapopulation. African Journal of Wildlife Research, 43, 61-67.

Faure, J.P.B., Holmes, N.J., Watson, L.H. \& Hill, R.A. (2019) Brown hyaena (Parahyaena brunnea) diet composition from Zingela Game Reserve, Limpopo Province, South Africa. African Zoology, 54, 119-124.
Fouché, J., Reilly, B.K., De Crom, E.P., Baeumchen, Y.K. \& Forberger, S. (2020) Density estimates of spotted hyaenas (Crocuta crocuta) on arid farmlands of Namibia. African Journal of Ecology, 58, 563-567.

Gaynor, K.M., Hojnowski, C.E., Carter, N.H. \& Brashares, J.S. (2018) The influence of human disturbance on wildlife nocturnality. Science, 35, 1232-1235.

Geldmann, J., Manica, A., Burgess, N.D., Coad, L. \& Balmford, A. (2019) A global-level assessment of the effectiveness of protected areas at resisting anthropogenic pressures. Proceedings of the National Academy of Sciences of the United States of America, 116, 23209-23215.

Grossmann, D., Holden, P.L. \& Collinson, R.F.H. (1999) Veld management on the game ranch. In Veld Management in South Africa (ed. N.M. Tainton), pp. 261-279. University of Natal Press, Pietermaritzburg, South Africa.

Gusset, M., Swarner, M.J., Mronwane, L., Keletile, K. \& MCNutT, J.W. (2009) Human-wildlife conflict in northern Botswana: livestock predation by Endangered African wild dog lycaon pictus and other carnivores. Oryx, 43, 67-72.

Hayward, M.W., Henschel, P., O’Brien, J., Hofmeyr, M., Balme, G. \& Kerley, G.I.H. (2006) Prey preferences of the leopard (Panthera pardus). Journal of Zoology, 270, 298-313.

Hayward, M.W., O’Brien, J. \& Kerley, G.I.H. (2007) Carrying capacity of large African predators: predictions and tests. Biological Conservation, 139, 219-229.

Höner, O.P., Wachter, B., East, M.L., Runyoro, V.A. \& Hofer, H. (2005) The effect of prey abundance and foraging tactics on the population dynamics of a social, territorial carnivore, the spotted hyena. Oikos, 108, 544-554.

Isaacs, L., Somers, M.J. \& Swanepoel, L. (in press) Density of African civets in a moist mountain bushveld region of South Africa. In Small Carnivores: Evolution, Ecology, Behaviour and Conservation (eds E. Do Linh San, J.J. Sato, J.L. Belant \& M.J. Somers). Wiley-Blackwell, Oxford, UK

Jordan, M.J., Barrett, R.H. \& Purcell, K.L. (2011) Camera trapping estimates of density and survival of fishers Martes pennanti. Wildlife Biology, 17, 266-276.

Kent, V.T. \& Hill, R.A. (2013) The importance of farmland for the conservation of the brown hyaena Parahyaena brunnea. Oryx, 47, 431-440.

Kery, M. \& Royle, J.A. (2016) Applied Hierarchical Modeling in Ecology: Analysis of Distribution, Abundance and Species Richness in $R$ and BUGS: Volume 1: Prelude and Static Models. Academic Press, Oxford, UK.

Lamb, C.T., Ford, A.T., McLellan, B.N., Proctor, M.F., Mowat, G., Ciarniello, L. et al. (2020) The ecology of human-carnivore coexistence. Proceedings of the National Academy of Sciences, $117,17876-17883$

Le Saout, S., Hoffmann, M., Shi, Y., Hughes, A., Bernard, C., Brooks, T.M. et al. (2013) Protected areas and effective biodiversity conservation. Science, 342, 803-805.

Lindsey, P.A., Balme, G., Becker, M., Begg, C., Bento, C., Bocchino, C. et al. (2013) The bushmeat trade in African savannas: impacts, drivers, and possible solutions. Biological Conservation, $160,80-96$

Mascia, M.B. \& Pailler, S. (2011) Protected area downgrading, downsizing, and degazettement (PADDD) and its conservation implications. Conservation Letters, 4, 9-20.

Maude, G. \& Mills, M.G.L. (2005) The comparative feeding ecology of the brown hyaena in a cattle area and a national park in Botswana. African Journal of Wildlife Research, 35, 201-214.

Mills, M.G.L., Juritz, J.M. \& Zucchini, W. (2001) Estimating the size of spotted hyaena (Crocuta crocuta) populations through 
playback recordings allowing for non-response. Animal Conservation, 4, 335-343.

Mucina, L. \& Rutherford, M.C. (2006) The Vegetation of South Africa, Lesotho and Swaziland. Strelitzia, South African National Biodiversity Institute, Pretoria, South Africa.

Nattrass, N. \& Conradie, B. (2018) Predators, livestock losses and poison in the South African Karoo. Journal of Cleaner Production, $194,777-785$.

Nogeire, T.M., Davis, F.W., Duggan, J.M., Crooks, K.R. \& Boydston, E.E. (2013) Carnivore use of avocado orchards across an agricultural-wildland gradient. PLOS ONE, 8, e68025.

O’Bryan, C.J., Braczkowski, A.R., Beyer, H.L., Carter, N.H., Watson, J.E.M. \& McDonald-Madden, E. (2018) The contribution of predators and scavengers to human well-being. Nature Ecology and Evolution, 2, 229-236.

Pitman, R.T., Fattebert, J., Williams, S.T., Williams, K.S., Hill, R.A., Hunter, L.T.B. et al. (2017a) Cats, connectivity and conservation: incorporating data sets and integrating scales for wildlife management. Journal of Applied Ecology, 54, 1687-1698.

Pitman, R.T., Fattebert, J., Williams, S.T., Williams, K.S., Hill, R.A., Hunter, L.T.B. et al. (2017b) The conservation costs of game ranching. Conservation Letters, 10, 403-413.

Pitman, R.T., Swanepoel, L.H., Hunter, L., Slotow, R. \& Balme, G.A. (2015) The importance of refugia, ecological traps and scale for large carnivore management. Biodiversity and Conservation, 24, 1975-1987.

Ramesh, T. \& Downs, C.T. (2015) Impact of land use on occupancy and abundance of terrestrial mammals in the Drakensberg Midlands, South Africa. Journal for Nature Conservation, 23, 9-18.

R Development Core Team (2016) R: A Language and Environment for Statistical Computing. R Foundation for Statistical Computing, Vienna, Austria.

Rich, L.N., Kelly, M.J., Sollmann, R., Noss, A.J., Maffei, L., ARISPE, R.L. et al. (2014) Comparing capture-recapture, mark-resight, and spatial mark-resight models for estimating puma densities via camera traps. Journal of Mammalogy, 95, 382-391.

Rich, L.N., Miller, D.A., Muñoz, D.J., Robinson, H.S., McNutt, J.W. \& Kelly, M.J. (2019) Sampling design and analytical advances allow for simultaneous density estimation of seven sympatric carnivore species from camera trap data. Biological Conservation, 233, 12-20.

Rodríguez, J.P., Simonetti, J.A., Premoli, A. \& Marini, M.Â. (2005) Conservation in Austral and neotropical America: building scientific capacity equal to the challenges. Conservation Biology, 19, 969-972.

Rogan, M.S., Balme, G.A., Distiller, G., Pitman, R.T., Broadfield, J., Mann, G.K.H. et al. (2019) The influence of movement on the occupancy-density relationship at small spatial scales. Ecosphere, 10, e02807.

Rogan, M.S., Lindsey, P.A., Tambling, C.J., Golabek, K.A., Chase, M.J., Collins, K. et al. (2017) Illegal bushmeat hunters compete with predators and threaten wild herbivore populations in a global tourism hotspot. Biological Conservation, 210, 233-242.

Šálek, M., Červinka, J., Pavluvěík, P., Poláková, S. \& TKADLEC, E. (2014) Forest-edge utilization by carnivores in relation to local and landscape habitat characteristics in central European farmland. Mammalian Biology, 79, 176-182.

Shamoon, H., Saltz, D. \& Dayan, T. (2017) Fine-scale temporal and spatial population fluctuations of medium sized carnivores in a Mediterranean agricultural matrix. Landscape Ecology, $32,1243-1256$.

Shannon, G., Angeloni, L.M., Wittemyer, G., Fristrup, K.M. \& Crooks, K.R. (2014) Road traffic noise modifies behaviour of a keystone species. Animal Behaviour, 94, 135-141.
Statistics South Africa (2011) Census 2011 Limpopo Municipal Report No. 03-01-57. statssa.gov.za [accessed 1 May 2019].

Swanepoel, L.H., Lindsey, P., Somers, M.J., van Hoven, W. \& Dalerum, F. (2013) Extent and fragmentation of suitable leopard habitat in South Africa. Animal Conservation, 16, 41-50.

Swanepoel, L.H., Somers, M.J. \& Dalerum, F. (2015) Density of leopards Panthera pardus on protected and non-protected land in the Waterberg Biosphere, South Africa. Wildlife Biology, 21, 263-268.

Thorn, M., Green, M., Bateman, P.W., Waite, S. \& Scott, D.M. (2011) Brown hyaenas on roads: estimating carnivore occupancy and abundance using spatially auto-correlated sign survey replicates. Biological Conservation, 144, 1799-1807.

Thorn, M., Green, M., Dalerum, F., Bateman, P.W. \& Scott, D.M. (2012) What drives human-carnivore conflict in the North West Province of South Africa? Biological Conservation, 150, 23-32.

Thorn, M., Scott, D.M., Green, M., Bateman, P.W. \& Cameron, E.Z. (2009) Estimating Brown Hyaena occupancy using baited camera traps. South African Journal of Wildlife Research, 39, 1-10.

van der Meer, E., Fritz, H., Blinston, P. \& Rasmussen, G.S.A. (2014) Ecological trap in the buffer zone of a protected area: effects of indirect anthropogenic mortality on the African wild dog Lycaon pictus. Oryx, 48, 285-293.

van der Ree, R., Jaeger, J.A.G., van der Grift, E.A. \& Clevenger, A.P. (2011) Effects of roads and traffic on wildlife populations and landscape function: road ecology is moving toward larger scales. Ecology and Society, 16, 48.

Veldhuis, M.P., Ritchie, M.E., Ogutu, J.O., Morrison, T.A., BeAle, C.M., Estes, A.B. et al. (2019) Cross-boundary human impacts compromise the Serengeti-Mara ecosystem. Science, $363,1424-1428$.

Vissia, S., Wadhwa, R. \& van LANGevelde, F. (2021) Co-occurrence of high densities of brown hyena and spotted hyena in central Tuli, Botswana. Journal of Zoology, 314, 143-150.

WELCH, R.J. \& PARKER, D.M. (2016) Brown hyaena population explosion: rapid population growth in a small, fenced system. Wildlife Research, 43, 178-187.

Williams, K.S., Williams, S.T., Fitzgerald, L.E., Sheppard, E.C. \& Hill, R.A. (2018b) Brown hyaena and leopard diets on private land in the Soutpansberg Mountains, South Africa. African Journal of Ecology, 56, 1021-1027.

Williams, S.T., Maree, N., Taylor, P., Belmain, S.R., Keith, M. \& Swanepoel, L.H. (2018a) Predation by small mammalian carnivores in rural agro-ecosystems: An undervalued ecosystem service? Ecosystem Services, 30, 362-371.

Williams, S.T., Williams, K.S., Lewis, B.P. \& Hill, R.A. (2017) Population dynamics and threats to an apex predator outside protected areas: implications for carnivore management. Royal Society Open Science, 4, 161090.

Williams, K.S., Williams, S.T., Welch, R.J., Marneweck, C.J., Mann, G.K., Pitman, R.T. et al. (2021) Assumptions about fence permeability influence density estimates for brown hyaenas across South Africa. Scientific Reports, 11, 1-11.

Winterbach, C.W., Maude, G., Neo-Mahupeleng, G., Klein, R., Boast, L., Rich, L.N. \& Somers, M.J. (2017) Conservation implications of brown hyaena (Parahyaena brunnea) population densities and distribution across landscapes in Botswana. Koedoe, 59, 1-16.

Wolf, C. \& Ripple, W.J. (2016) Prey depletion as a threat to the world's large carnivores. Royal Society Open Science, 3, 160252.

Wolf, C. \& Ripple, W.J. (2017) Range contractions of the world's large carnivores. Royal Society Open Science, 4, 170052.

Woodroffe, R. \& Ginsberg, J.R. (1998) Edge effects and the extinction of populations inside protected areas. Science, 280, 2126-2128. 